\title{
Property rights economics
}

\section{Nicolai J Foss}

The decade of the 1960s was extraordinarily fertile in applied as well as formal

microeconomics. Thus the decade witnessed fundamental breakthroughs in the economics of uncertainty and information, human capital theory, the first stabs at what would later be called 'agency theory' and 'mechanism design', and other advances in mathematical economics.

One of the important breakthrough theories of the 1960s was property rights economics (PRE). 'First-generation' property rights economists such as Armen Alchian, Ronald Coase, Harold Demsetz, and (Coase student) Steven Cheung developed a refined but mainly verbal approach to an economic explanation that they saw, and advertised, as fundamentally neoclassical but with a much wider explanatory reach. Their work served as direct inspiration for the slightly later work of the 'second-generation' PRE theorists such as Louis De Alessi, Yoram Barzel, Eirik Furubotn, Douglass North, Steven Pejovich, and John Umbeck. Modern (third-generation) representatives of the PRE are Douglas Allen, Lee Alston, Thrainn Eggertson, Gary Libecap, Dean Lueck, Ellinor Ostrom, and others. A different approach, emerging in the mid-1980s (Grossman \& Hart, 1986), growing out of formal contract theory as well as key ideas in transaction cost economics (TCE), and associated with the work of Oliver Hart and his colleagues and students, is often also referred to as the 'property-rights approach'. This approach will be briefly discussed towards the end of the chapter.

PRE has been directly and strongly influential in law and economics (Coase, 1960), economic history (Alchian \& Demsetz, 1973; North, 1990), the theory of the firm (Alchian \& Demsetz, 1972), contract economics (e.g., Cheung, 1970; Allen \& Lueck, 1995), early comparative systems research (cf. Furubotn \& Pejovich, 1972), and resource and agricultural economics (e.g., Cheung, 1969; Allen \& Lueck, 1998). It has had a large, but less direct, influence on industrial organisation, agency theory, and corporate governance (including the 'Yugoslav firm' debate as well as the debate on 'co-determination', cf. Furubotn \& Pejovich, 1972).

The basic analytical category proffered by the PRE is, of course, that of property rights, and the main explanatory aims have consistently been to investigate how the delineation, 
exchange, and enforcement of property and ownership rights influence resource allocation, and how this frames an economic approach to institutions and organisations. Thus, in a number of ways, the PRE is akin in its aims to transaction cost economics. Both acknowledge a fundamental debt to the thinking of Coase $(1937,1960)$ (Barzel, 1992; Williamson, 1996), both place the notion of transaction costs centre stage in the explanatory structure of the theory, and there is some overlap in terms of explanandum phenomena. However, there are also important differences, most obviously that the PRE is more directly situated within neoclassical economics than is TCE.

\section{Property rights}

Property-rights theorists often portray the PRE as fundamentally an extension of neoclassical economics, in the sense that (1) the utility-maximisation hypothesis be applied to virtually all choices (Alchian, 1958, 1965; Barzel, 1997), (2) it considers all of the constraints implied by the prevailing structure of property rights and transaction costs (e.g., Demsetz, 1964; Alessi, 1990), and (3) it explicitly considers the contractual, organisational, and institutional implications of (1) and (2) (Eggertson, 1990). In sum, introducing the notion of property rights very significantly extends the reach of economic thinking because it expands and refines the understanding of individuals' opportunity sets.

While true, this is also something of a retrospective rationalisation. The PRE actually begins by introducing a new unit of analysis in a specific context, namely the analysis of externalities in Coase (1960), and the three characteristics above unfolded only gradually over the following decade. For example, the full implications of the zero-transaction-costs assumption - for example, that if transaction costs are zero monopolies do not influence resource allocation (Demsetz, 1964) and that all institutional alternatives are efficient (Cheung, 1969) - were not present in PRE thinking from the beginning, and are indeed still under debate (e.g., Furubotn, 1992; Barzel, 1997).

Thus, the unit of analysis in PRE is the property right. As indicated already, the first paper to put forward the property right explicitly as a meaningful unit of analysis is Coase (1960), although the property-rights ideas in that famous paper are anticipated in Coase's 1959 paper on the allocation of radio frequencies (Coase, 1959) and a paper that same year by Armen Alchian (1959). Coase (1960) examines the economic implications of allocating legally delineated rights (liability rights) to a subset of the total uses of an asset, namely those that have external effects on the value of other agents' abilities to exercise their use rights 
over assets. As part of his critique of the Pigouvian tradition in welfare economics, Coase (1960, p. 155) notes that a reason for its failure to come fully to grips with externality issues lies in its 'faulty concept of a factor of production,' which, according to Coase, should be seen not as a physical entity but as a right to perform certain actions. These rights are property rights.

A fundamental insight emerging from Coase's work is that transactions involve the exchange of property rights (rather than goods and services per se). As Coase explained, property rights to an asset can be partitioned in various ways. Much subsequent work within PRE refined this insight, applying it to issues like public ownership and the public corporation. Yoram Barzel's (1997) work in particular has been taken up with examining the consequences of the multi-attribute nature of most assets. It had long been recognised, of course, that some rights may be held in common, with open access, while other rights are held in private (Knight, 1924). However, unfolding the concept of property rights and its application to the public-private spectrum revealed that the range of property rights is very extensive indeed (Alessi, 1990). This led to a highly sophisticated analysis of how the property rights associated with an asset impact individual incentives, because property rights are fundamentally about whom should bear the consequences of choices involving the relevant asset. Like the rest of economics, PRE assumes that behaviours vary predictably as a consequence of such incentives.

\section{Characteristics of property rights}

Analysis of the nature of property rights has clearly evolved within the PRE. Coase (1960) was mainly interested in the allocation of use rights to assets. Demsetz (1964) and Alchian (1965) went beyond this, defining property rights as individuals' rights to the use, income, and transferability of assets, a definition corresponding to the partition in Roman law between usus, fructus, and abusus, respectively. ${ }^{1}$ The relation to property law was also debated. It became increasingly clear that property rights can be analysed conceptually apart from legal considerations (some scholars therefore talk about 'economic rights', e.g., Barzel, 1997). In fact, it was recognised that property rights may exist in the absence of the state, that is, under wholly anarchic conditions (Bush \& Mayer, 1974; Umbeck, 1981). Physical force or strong social norms may guarantee de facto control over the uses of and income from a resource. It also became clear that property rights have an inherently forward-looking dimension and that, therefore, uncertainty is an important aspect of property rights. Finally, it became clear that 
from an economic perspective property rights can be understood in value terms and that agents seek to maximise the value of the control they hold over assets.

In line with such ideas, Alchian and Allen (1969, p. 158) offered a highly compact definition of property rights as 'the expectations a person has that his decision about the uses of certain resources will be effective' (see also Cheung, 1970). Barzel (1994, p. 394; emphasis in original) explains property rights as

an individual's net valuation, in expected terms, of the ability to directly consume the services of the asset, or to consume it indirectly through exchange. A key word is ability: The definition is concerned not with what people are legally entitled to do but with what they believe they can do.

Essentially, property rights in such definitions refer to an individual's expected opportunity set, and they imply that even Robinson Crusoe would hold property rights. They also suggest that the definition of a property right is independent of legal considerations; to the extent that he holds effective control over an asset, a thief holds property rights to that asset (Barzel, 1997). However, although property rights may thus exist potentially in the absence of law, in reality they have legal counterparts and the value of property rights is influenced by legal sanction and enforcement (Barzel, 1997). Not surprisingly, many property rights scholars have strongly stressed the fundamentally social nature of property rights.

Thus, Demsetz (1967, p. 347) argues that

[i]n the world of Robinson Crusoe property rights play no role. Property rights are an instrument of society and derive their significance from the fact that they help a man form those expectations which he can reasonably hold in his dealings with others. These expectations find expression in the laws, customs, and mores of a society. An owner of property rights possesses the consent of fellowmen to allow him to act in particular ways. An owner expects the community to prevent others from interfering with his actions, provided that these actions are not prohibited in the specifications of his rights.

\section{Levels of analysis}

Such definitions direct attention to 'macro' determinants of property rights such as norms, customs, and law. Of course, norms defining property rights can exist on lower levels, such as within or between firms. Thus, corporate culture (Jones, 1983) and relational contracting (Williamson, 1996) serve to delineate and enforce property rights. Moreover, property rights are, of course, allocated in formal contracts. This suggests distinguishing various analytical 
levels at which property rights can be enforced. (Of course, property rights also exist on various levels, e.g., both natural and corporate persons can hold property rights). Indeed such a distinction has been made in the PRE literature, notably in the work of Douglass North (1990), whose distinction between organisations and institutions captures the difference between the more micro property-rights arrangements in the form of contracts and organisations and the macro property regimes embodied in laws, customs, and the coercive machinery of the state.

\section{Property rights and transaction costs}

Transaction costs were introduced by Coase in his 1937 paper on the firm (Coase, 1937), well before the 1960 paper on social cost (Coase, 1960). Arguably, one reason so little progress was made on the analysis in the first paper is that transaction costs are difficult to define without a clear conception of property rights (Barzel and Kochin, 1992). However, Coase (1960) does not systematically derive transaction costs from property rights. Instead, he defines the former as search costs, communication costs, bargaining costs, contract drafting costs, and contract monitoring costs of monitoring (Coase, 1960, p. 114). Thus, transaction costs in Coase (1960) are a more refined version of the 'costs of using the price mechanism' introduced by Coase (1937) (Cheung, 1969). Indeed, the link between property rights and transaction costs that interests Coase (1960) is the fact that when transaction costs are positive, property rights are ill-defined, which reduces attainable output. Of course, this link between inputs, 'organisation,' and allocative consequences provided a vital overall framing that was crucially important for future thinking on the theory of the firm (Barzel and Kochin, 1992).

Alchian's (1958) almost simultaneous examination of the absence of private property rights in government links transaction costs and property rights in a different way. Alchian develops a general argument that government assets are insufficiently protected and that this leads to a failure of marginal pricing and use of government services. Thus, insecure property rights induce costly racing to capture wealth, an argument later refined in several contributions to the PRE (e.g., Anderson and Hill, 1990; Lueck, 1995). Thus, transaction costs as waste result from ill-defined or ill-protected property rights.

Actually, both causal processes (i.e., transaction costs leading to ill-defined property rights, and ill-defined and ill-protected property rights leading to transaction costs) take place, and the overall PRE perspective on contracts, organisations, and institutions is that these exist 
to minimise the allocative distortions implied by both processes (Eggertson, 1990; Lueck, 1995). Thus, in terms of the property-rights view of Hart (1995) transaction costs of drafting contracts make contracts incomplete (i.e., property rights are ill-defined). This gives rise to a loss in terms of inefficient investments, which may also be seen as transaction costs, because it is an allocative distortion induced by direct transaction costs. In Williamson's (1996) thinking, ill-defined contractual rights give rise to processes of costly ex post haggling.

Still, transaction costs are probably most conveniently defined in terms of property rights, and most of the PRE has done exactly this. Thus, transaction costs can be defined as the resources spent on delineating, protecting, and capturing control over resources in use and in exchange (Eggertson, 1990; Barzel, 1997). A particular case of transaction costs are the measurement costs of inspecting attributes of goods and services elegantly analysed by Barzel (1982). A famous benchmark case obtains when transaction costs are zero: In what has become known as the 'Coase theorem' (Stigler, 1966), Coase (1960) shows that if transaction costs are zero - so that any property right can be costlessly delineated and protected - any allocation of property rights results in the same pattern of economic activities under which maximum value is created from the use of resources. ${ }^{2}$ The mechanisms underlying this remarkable result are that (1) property rights to all possible uses of resources are delineated, (2) all property rights are priced, and (3) all property rights can be traded - all at zero cost. Maximising agents will have incentives to trade property rights so that resources end up in those uses where their contribution to value creation is maximised. The Coase theorem is no doubt one of the most extensively debated pieces of economic thinking (e.g., Cooter, 1982; Usher, 1998). While it is surely warranted to devote resources to clarifying key benchmark constructs, the Coase theorem is, as Coase emphatically insists (Coase, 1988b), just that: a benchmark designed to serve as a starting point for analysis involving transaction costs.

\section{The PRE and transaction cost economics}

Of course, transaction costs are also central to Williamsonian transaction cost economics, and PRE and TCE share many important features. The PRE emerged first; Furubotn and Pejovich's (1972) and Alchian and Demsetz's (1973) stock takings of accomplishments since Coase (1960) were published when TCE was in its infancy (Williamson, 1971). However, the influence of the PRE on Williamson's thinking seems fairly limited. He does not use property-rights terminology, is critical of specific PRE papers (e.g., see the critique of 
Alchian an Demsetz, 1972, in Williamson, 1985), characterises the PRE as a distinct approach (e.g., characterising Barzel's work as the 'measurement approach' in Williamson, 1985), and sees property rights lying on a higher analytical level than his own concern with levels of analysis that involve the firm (Williamson, 2000). Moreover, certain distinct features set Williamson's thinking apart from that of most property-rights economists. In particular, Williamson's insistence on bounded rationality does not resonate with all scholars associated with PRE (e.g., Barzel and Kochin, 1992, p. 441). On the other hand, key PRE scholar Armen Alchian is one of the originators of the emphasis on the problems caused by asset specificity in the context of incomplete contracting (Klein, Crawford and Alchian, 1978). The treatment of this problem and its remedies is a key concern in TCE, and is not inconsistent with the PRE.

\section{Property rights economics: old and new}

Much work in PRE has focused on differences between property-rights systems as alternative ownership arrangements (collective versus private ownership). However, the economic meaning of asset ownership does not seem to be pinned down precisely in PRE. Coase (1960) thinks of private ownership as possession of 'the right to carry out a circumscribed list of actions' (idem.); that is, private ownership of an asset is the possession of a vector of use rights for that asset. However, ownership per se is what primarily interests Coase; his major concern is the allocation of use rights. Conceptually, this allocation can be separated from the ownership, because one can imagine that all possible uses (including future ones) of assets are known and can be contracted for (indeed, this is one possible interpretation of the Coase theorem). Under this interpretation, the concept of ownership and the issue of who owns an asset are unimportant if transaction costs are zero. Even when Coase relaxes the zerotransaction-cost assumption, his interest lies more in understanding the allocative consequences of different legal arrangements of use rights than ownership issues. Thus, a major problem left unaddressed by Coase is how far one needs to 'relax' the assumptions underlying the Coase theorem to produce a role for ownership.

Coase's understanding also left unresolved the role played by other types of economic rights besides use rights, such as income and alienability rights, in the function of ownership. What economic considerations determine the allocation of these rights? The PRE only partially succeeded in giving answers to the puzzles left by Coase. In fact, Demsetz (1988, p. 19) argues that the meaning of ownership is inherently 'vague' because there is no bound to 
the number of attributes, uses, etc. of an asset that can be owned, although he thinks that 'certain rights of action loom more important than others. Exclusivity and alienability are among them'. ${ }^{3}$ Perhaps because of the perceived vagueness of the notion of ownership, PRE scholars have been more concerned with the efficiency consequences of property-rights allocation across agents when transaction costs are positive than the issue of 'who owns an asset'.

At the same time, ownership has a concrete meaning in the law: both legislation and jurisprudence distinguish the law relating to contract from the law relating to asset ownership. The law relating to ownership is more than simply part of a low-cost enforcement institution; it provides default rules or a 'standard contract' that reduces information and communication costs and has allocative consequences for this reason. Moreover, legal ownership is a lowcost way of allocating hitherto undiscovered uses of assets. For example, giving people legal ownership implies that they hold the legal right to future, as yet undiscovered, attributes of assets, in the sense that courts will not interfere with the use of these assets by the parties identified as the owners. In fact, the overall thrust in economics thinking about property rights has changed from the focus of the PRE (i.e., the allocation of rights to an asset across multiple agents) to the issue who owns an asset and why this matters, the key concern of what may be called the 'new’ PRE (Grossman and Hart, 1986; Hart, 1995).

Historically and theoretically, the new PRE has been developed in the context of the theory of the firm, more precisely the analysis of the vertical boundaries of the firm (Grossman and Hart, 1986), the key explanandum of TCE. Indeed, while contributors to the new PRE routinely make reference to Williamson, references to the old PRE are conspicuous by their absence from the new PRE.

The new PRE approach begins with the idea that ownership of nonhuman assets is what defines the firm; if two different assets are owned by one person, there is with one firm, while if the same two assets are owned by different persons, there are two firms. The assets that are relevant here are nonhuman assets, because human assets are non-alienable. The importance of nonhuman assets derives from their (potential) function as bargaining levers in situations not covered by contract. This may be crucially important when parties invest in specific assets - notably, investments in the parties' own human capital - and these assets are complementary to specific nonhuman assets. Crucially, the parties' investments in human assets are assumed to be non-contractible. All bargaining after the parties have made their investments in human assets is assumed to be efficient (in marked contrast to, e.g., 
Williamson 1996). Therefore, the model revolves around the effect of ownership of nonhuman assets on the incentives to invest in human assets. Specifically, bargaining determines the allocation of returns from investments, so that each party gets his opportunity cost plus a share (assumed equal) of the (verifiable) profit stream. Since in this setup individual returns differ from social returns, and agents are sufficiently farsighted to foresee this, investments will be inefficient.

It is possible to influence the investment of one of the parties positively by reallocating ownership rights to nonhuman assets. A reallocation of ownership of physical assets alters the parties' opportunity costs of non-cooperation (the status quo) after specific investments have been made, and thus the expected payoffs from the investments. However, this comes only at the cost of reducing one of the parties' investment incentives (excepting the situation in which the parties' marginal costs of investment are equal). This trade-off determines allocation of ownership and hence the efficient boundaries of the firm. Thus, the central issue who owns an asset or a bundle of assets. Underlying this focus is the idea that it is possible to identify unambiguously the owner of an asset.

A central idea in the new PRE is the distinction between specific rights of control and residual rights of control. The former can be delineated and directly allocated through contract, while the latter are obtained through the legal ownership of assets and imply the 'right to decide usages of the asset in uncontracted-for contingencies' (Hart 1996, p. 371). However, residual control rights encompass not only the rights to use assets, but also to 'decide when or even whether to sell the asset' (Hart, 1995, p. 65). In the new PRE ownership is defined as the legally enforced possession of an asset. The economic importance of ownership stems from the owner's ability to exercise residual rights of control over the assets. This economic conception is thus explicitly derived from the juristic conception. In other words, the function of ownership is to allocate residual rights of control. Thus, the meaning of ownership, and its relation to property rights and the legal system are addressed straightforwardly.

At first glance the new PRE notion of residual rights of control appears to be a conceptual sword cutting through the Gordian knot of the meaning of ownership in the old PRE literature. However, it does so by means of some drastic simplifications (Foss and Foss, 2001). Recall that a key point in the old PRE is an explicit distinction between the formal, legal title to an asset and the economic rights to that asset (e.g., Coase, 1960; Alchian, 1965; Barzel, 1997). In the presence of transaction costs (particularly measurement and 
enforcement costs), this distinction is important for any asset, whether human capital or nonhuman capital. While these two asset categories are treated symmetrically in the old PRE, the new PRE treats them differently. In the new PRE ownership to, and contracts over, physical assets are assumed to be fully and costlessly enforced by the legal system, but contracts involving investments in human capital are assumed to be completely unenforceable because of an asserted non-verifiability. Foss and Foss (2001) argue that this asymmetry underlies the difficulty in the new PRE in conceptualising the difference between quasi-vertical and vertical integration and to explain the employment contract.

\section{Conclusion}

Relatively few economists today define themselves as working in the old PRE tradition. Over the last two decades, property rights have received attention mainly because of the new PRE. It might thus appear that the old PRE is essentially defunct, that its largely verbal mode of discourse has been supplanted by the heavily formal approach of the new PRE. This view is naïve, however. First, the new PRE is a considerably narrower approach in terms of the phenomena it investigates. Second, the reason that relatively little old PRE research appears in today's economics journals may be the old PRE's success: property-rights reasoning has penetrated applied price theory, the theory of economic organisation, agricultural economics, and many other fields, changing these fields in the process. Still, creative work lying directly in the old PRE tradition continues to be carried out by scholars such as Doug Allen, Yoram Barzel, Thrainn Eggertson, Dean Lueck, and others.

\section{References}

Alchian, A.A. (1958), 'Private Property and the Relative Cost of Tenure,' in P.D. Bradley, ed., The Public Stake in Union Power, Charlottesville, Va., University of Virginia Press, 350-371.

Alchian, A. A. (1965), ‘Some Economics of Property Rights,' in idem, Economics Analysis of Property Rights,(1977) Indianapolis: Liberty Press.

Alchian, A. A. \& W. R. Allen, (1969), Exchange and Production: Theory in Use, Belmont: Wadsworth.

Alchian, A. A. \& H. Demsetz. (1973), 'The Property Rights Paradigm,' Journal of Economic History 33, 16-27.

Alessi, L. (1983), 'Property Rights, Transaction Costs, and X-Efficiency: An Essay in Economic Theory,' American Economic Review 73, 64-81. 
Alessi, L. (1990), 'Development of the Property Rights Approach,' Journal of Institutional and Theoretical Economics 146, 6-11.

Allen, D.W. \& D Lueck, (1995), 'Risk Preferences and the Economics of Contracts,' American Economic Review 85 (Papers and Proceedings), 447-451

Allen, D. \& D. Lueck, (1998), 'The Nature of the Farm,' Journal of Law and Economics 41, 343-386.

Anderson, T.L. \& P. J. Hill, (1990), 'The Race for Property Rights,' Journal of Law and Economics 33, 177-197.

Barzel, Y. (1982), 'Measurement Costs and the Organization of Markets,' Journal of Law and Economics 25, 27-48.

Barzel, Y. (1994), 'The Capture of Wealth by Monopolists and the Protection of Property Rights,' International Review of Law and Economics 14, 393-409.

Barzel, Y. (1997), Economic Analysis of Property Rights, 2nd ed., Cambridge: Cambridge University Press.

Barzel, Y. \& L. Kochin, (1992), 'Ronald Coase on the Nature of Social Cost as a Key to the Problem of the Firm,' Scandinavian Journal of Economics 94, 19-31.

Bush, W. \& L. Mayer, (1974), 'Some Implications of Anarchy for the Distribution of Property,' Journal of Economic Theory 8, 401-412.

Cheung, S.N.S. (1969), 'Transaction Costs, Risk Aversion, and the Choice of Contractual Arrangements,' Journal of Law and Economics 12, 23 - 42.

Cheung, S.N.S. (1970), 'The Structure of a Contract and the Theory of a Non-Exclusive Resource,' Journal of Law and Economics 13, 49-70.

Cheung, S.N.S. (1983), 'The Contractual Nature of the Firm,' Journal of Law and Economics 26, 1-21.

Clay, K. and G. Wright, (2005), 'Order without Law? Property Rights during the California Gold Rush,' Explorations in Economic History 42, 155-183.

Coase, R. H. (1937), 'The Nature of the Firm,' in idem, (1988), The Firm, the Market and the Law, Chicago: University of Chicago Press.

Coase, R.H. (1959), ‘The Federal Communications Commission, ‘ Journal of Law and Economics 2, 1-40.

Coase, R. H. (1960), 'The Problem of Social Cost,' in idem, (1988), The Firm, the Market and the Law, Chicago: University of Chicago Press.

Coase, R. H. (1988a), The Firm, the Market and the Law, Chicago: University of Chicago Press. 
Coase, R. H. (1988b), 'Notes on the Problem of Social Cost,' in idem, (1988), The Firm, the Market and the Law, Chicago: University of Chicago Press.

Cooter, R. (1982), ‘The Cost of Coase,’ Journal of Legal Studies 11, 1-33.

Demsetz, H. (1964), ‘The Exchange and Enforcement of Property Rights,’ Journal of Law and Economics 7, 11-26.

Demsetz, H. (1967), 'Toward a Theory of Property Rights,' originally published in (1967), reprinted in H. Demsetz, (1988), Ownership, Control, and the Firm, Oxford: Basil Blackwell.

Demsetz, H. (1982), 'Barriers to Entry,’ American Economic Review 72, 47-57.

Demsetz, H. (1988, ‘A Framework for the Study of Ownership,' in H. Demsetz, Ownership, Control, and the Firm, Oxford, Basil Blackwell.

Demsetz, H. (1998), 'Review: Oliver Hart, “Firms, Contracts, and Financial Structure”,' Journal of Political Economy, (1998), 106, 446-452.

Eggertson, T. (1990), Economic Behavior and Institutions, Cambridge, Cambridge University Press.

Foss, K. \& N.J. Foss, (2001), ‘Assets, Attributes, and Ownership’, International Journal of the Economics of Business 8, (19-37.

Furubotn, E. \& S. Pejovich, (1972), 'Property Rights and Economic Theory: A Survey of Recent Literature,’ Journal of Economic Literature 10, 1137-1162.

Furubotn, E.G. (1991), 'General equilibrium models, transaction costs, and the concept of efficient allocation in a capitalist economy,' Journal of Institutional and Theoretical Economics 147, 662-686.

Grossman, S. \& O. Hart, (1986), 'The Costs and Benefits of Ownership: A Theory of Lateral and Vertical Integration,' Journal of Political Economy 94, 691-719.

Hart, O. (1995), Firms, Contracts and Financial Structure, Oxford: Clarendon Press, Hart, O. (1996), ‘An Economist’s View of Authority,' Rationality and Society 8, 371-386.

Hart, O. \& J. Moore, (1990), 'Property Rights and the Nature of the Firm,' Journal of Political Economy 98, 1119-1158.

Knight, F.H. (1924), 'Some Fallacies in the Interpretation of Social Cost,' Quarterly Journal of Economics 38(4), 582-606.

Libecap, G. P. (1989), Contracting for Property Rights, Cambridge, Cambridge University Press.

Lueck, D. (1995), 'The Rule of First Possession and the Design of the Law,' Journal of Law and Economics 38, 393-436. 
North, D.C. (1990), Institutions, Institutional Change, and Economic Performance, Cambridge: Cambridge University Press.

Umbeck, J. (1981), 'Might Makes Rights: A Theory of the Formation and Initial Distribution of Property Rights,' Economic Inquiry 19, 38-59.

Usher, D. (1998), 'The Coase theorem is tautological, incoherent or wrong,' Economics Letters 61, 3-11.

Stigler, G.J. (1966), The Theory of Price, New York, MacMillan.

Wallis, J. J. \& Douglass C. North, (1986), 'Measuring the Transaction Sector in the American Economy, 1870-1970,' in S. L. Engerman \& R. E. Gallman, eds., Long-Term Factors in American Economic Growth, Chicago: University of Chicago Press.

Williamson, Oliver E. (1971), 'The Vertical Integration of Production: Market Failure Considerations,' American Economic Review 61, 112-123

Williamson, O.E. (1985), The Economic Institutions of Capitalism, New York, The Free Press.

Williamson, O.E. (1996), The Mechanisms of Governance, Oxford, Oxford University Press. Williamson, O.E. (2000), 'The New Institutional Economics: Taking Stock, Looking Ahead,' Journal of Economic Literature 38, 595-613

\section{Notes}

$1 \quad$ Legal scholars may distinguish between 'property' (i.e., having usus, fructus, and abusus rights) and 'possession' (i.e., having only usus and abusus rights). However, PRE theorists think of all these rights as 'property rights.' See Foss and Foss (2001).

2 And there are no 'wealth effects', that is, individuals do not change their consumption patterns and firms do not change their investment patterns when they obtain more wealth.

3 Typically, ownership has been defined in this literature depending on the analytical purpose. For example, Demsetz and Alchian both put much emphasis on the rights to exclude and alienate as the relevant criteria of private ownership in their work on systems of property rights, and see owners as those agents who can exercise these rights (Alchian, 1965; Demsetz, 1967). However, they slightly change these latter criteria when they analyze the organization of the firm and corporate governance, where owners becomes defined as those possessing control rights (Demsetz, 1967) or residual income rights (Alchian \& Demsetz, 1972). 